\title{
Increased Frequency of Antigen-Specific Polyfunctional T Cells in Tuberculosis Patients
}

\author{
Basirudeen Syed Ahamed Kabeer, Anbalagan Selvaraj, and Alamelu Raja \\ Department of Immunology, National Institute of Research in Tuberculosis (ICMR), Mayor V.R. Ramanathan Road, Chetput,
} Chennai, Tamil Nadu 600 031, India

Correspondence should be addressed to Alamelu Raja; alameluraja@gmail.com

Received 27 May 2013; Accepted 5 July 2013

Academic Editors: C. M. Artlett and A. Taylor-Robinson

Copyright (c) 2013 Basirudeen Syed Ahamed Kabeer et al. This is an open access article distributed under the Creative Commons Attribution License, which permits unrestricted use, distribution, and reproduction in any medium, provided the original work is properly cited.

\begin{abstract}
This study assessed the polyfunctional T cells in healthy household contacts (HHCs) and TB patients. This study also assessed the memory subsets responsible for the secretion of IFN- $\gamma$ during the short-term culture with Mycobacterium tuberculosis antigens. Frequencies of CD $4^{+}$IFN- $\gamma^{+}$TNF- $\alpha^{+}$T cells and CD ${ }^{+}$IFN- $\gamma^{+}$TNF- $\alpha^{+}$T cells specific to $M$. tuberculosis antigens were significantly higher in TB patients compared to HHC. IFN- $\gamma$-secreting T cells, during overnight stimulation with $M$. tuberculosis antigens, belonged to effector memory subset with a CD45RA ${ }^{-} \mathrm{CD} 27^{-}$phenotype. However, the number of IFN- $\gamma$-secreting effector memory cells did not differ between HHC and TB patients.
\end{abstract}

\section{Introduction}

Tuberculosis (TB) is a global health problem with 2 billion people infected with the causative agent Mycobacterium tuberculosis (M. tuberculosis). Of these, only 10 percent will progress to active TB disease resulting in almost 2 million deaths per year [1]. This provides compelling evidence that the human immune system is capable of controlling the pathogen. However, the precise mechanisms contributing to the loss of immune control and progression of active TB disease are not known. A better understanding of these processes is critical for the development of improved diagnostics, treatment protocols, and vaccines.

It has been long recognized that Interferon gamma (IFN$\gamma$ ) producing $\mathrm{T}$ cells provide the major effector response in TB [2-5]. However, assessment of IFN- $\gamma$ producing T cells alone may not be sufficient. Further analysis of various $\mathrm{T}$ cell memory subsets, such as central memory and effector memory subsets, may provide some light in understanding the $\mathrm{T}$ cell protection in $\mathrm{TB}$.

$\mathrm{T}$ cells are able to produce multiple factors simultaneously and they are termed polyfunctional $\mathrm{T}$ cells. The evidence from animal and human models of chronic viral infections indicates that high levels of chronic antigen stimulation lead to functional impairment of antigen-specific $\mathrm{T}$ cell responses, with reduced cytokine production, cytotoxicity, and proliferative capacity [6-11]. The capacity of antigen-specific $\mathrm{T}$ cells to produce multiple cytokines simultaneously has been associated with superior functional capacity [12] and has been correlated with control of human chronic viral infections such as human immunodeficiency virus (HIV) [13-15] and hepatitis C virus (HCV) [16]. Moreover, polyfunctional T cells have been associated with protection against disease progression in mouse models of Leishmania major [17] and M. tuberculosis [18]. Polyfunctional T cells, which produce IFN- $\gamma$, IL-2, and TNF- $\alpha$, have been described in studies of $M$. tuberculosis infected adults $[19,20]$, but they ended up with contradicting results.

In this study, we have enumerated the polyfunctional $\mathrm{T}$ cells in QuantiFERON-TB Gold in-tube (QFT-IT) positive HHC and QFT-IT positive TB patients. We also looked into the contribution of different memory $\mathrm{T}$ cell subset in the secretion of IFN- $\gamma$ during short-term culture with TB antigens.

\section{Material and Methods}

This study protocol was approved by the Institutional Ethical Committee of the National Institute of Research in 
Tuberculosis (NIRT), India. NIRT was formerly known as Tuberculosis Research Center. An informed written consent was obtained from study subjects before the blood was drawn.

2.1. Study Subjects. A total of 50 study subjects, who were positive for QFT-IT, were selected for this study. Among them, 25 were healthy household contacts (HHCs), and 25 subjects were newly diagnosed active pulmonary TB patients. All the study subjects were recruited at the National Institute for Research in Tuberculosis (NIRT), Chennai, India. Active TB was confirmed by identification of M. tuberculosis by culture from at least one of the 3 sputum samples. None of the TB patients had previous history of TB, and all were naïve for the antituberculous therapy. The age range of TB was from 28 to 52 years with a median of 36 years. Of them, $75 \%$, were males.

HHCs were identified from families, where there was at least one case of sputum positive pulmonary TB living in the same household, for at least 3 months immediately preceding the start of treatment of the index case. Among the $25 \mathrm{HHCs}$, $62 \%$ were males, and their age ranged from 25 to 55 years, with a median of 32 years. All were naïve for TB prophylaxis treatment.

\subsection{Isolation of Peripheral Blood Mononuclear Cells (PBMCs).} PBMCs were isolated by density gradient centrifugation by carefully layering heparinized blood over an equal volume of Histopaque (Sigma-Aldrich Corp., St. Louis, MO, USA) and spinning at $18^{\circ} \mathrm{C}$ for 30 minutes at $2000 \mathrm{rpm}$. The buffy coat containing peripheral blood mononuclear cells was removed, washed twice using Hanks' balanced salt solution (HBSS) (Sigma-Aldrich Corp, St. Louis, MO, USA), and resuspended in complete medium consisting of RPMI 1640 (SigmaAldrich Corp., St. Louis, MO, USA), 2 mM L-glutamine, 1\% 100X Antibiotic Antimycotic Solution (Invitrogen Corp., CA, USA), and $10 \%$ heat, inactivated human AB-serum (SigmaAldrich Corp. MO, USA).

2.3. In Vitro Culture. PBMCs were stimulated overnight in the presence of PPD, ESAT- 6 , and CFP-10 proteins at the concentration of $5 \mu \mathrm{g} / \mathrm{mL}$ or absence of any stimulant in a $37^{\circ} \mathrm{C}, 5 \% \mathrm{CO}_{2}$ incubator. Just 4 hours prior to stopping the reaction, $5 \mu \mathrm{g} / \mathrm{mL}$ of Brefeldin A was added to each well. After overnight incubation, the cells were washed with HBSS and used for downstream process.

2.4. Intracellular Cytokine Assay. Cytokine-(IFN- $\gamma$, TNF- $\alpha$ and IL-2) secreting T cells were enumerated by intracellular cytokine staining method. Briefly, cells were washed and labelled with fluorochrome-conjugated antibodies for surface proteins. Then, the cells were fixed using Cytofix/Cytoperm buffer (BD Biosciences, San Jose, CA, USA) and Washed with Perm/wash buffer (BD Biosciences, San Jose, CA, USA). The cells were then stained for intracellular cytokines. After washing, cells were fixed using $1 \%$ paraformaldehyde. The following combination of antibodies is used. To identify multiple cytokine-secreting polyfunctional T cells, cells were stained with CD4 PE-Cy5 or CD8 PE-Cy5, IL-2 APC, IFN- $\gamma$
TABLE 1: Enumeration of antigen-specific IFN- $\gamma$, IL-2, and TNF- $\alpha$ T cells in HHC and TB patients.

\begin{tabular}{lcccc}
\hline Cytokine & Antigen & $\begin{array}{c}\text { HHC } \\
\text { median (range) }\end{array}$ & $\begin{array}{c}\text { TB } \\
\text { median (range) }\end{array}$ & $P$ value \\
\hline \multirow{5}{*}{ CD4 IFN- $\gamma$} & PPD & $0.30(0-4.4)$ & $0.9(0-5.6)$ & 0.137 \\
& ESAT-6 & $0.39(0.09-3.4)$ & $0.8(0.1-3.8)$ & 0.101 \\
& CFP-10 & $0.36(0.1-6.7)$ & $0.67(0.13-2.4)$ & 0.747 \\
CD8 IFN- $\gamma$ & PPD & $0.35(0.1-2)$ & $0.52(0-1.4)$ & 0.901 \\
& ESAT-6 & $0.43(0.04-1.9)$ & $0.56(0-1.8)$ & 0.989 \\
& CFP-10 & $0.24(0.1-1.1)$ & $0.48(0.06-2.0)$ & 0.089 \\
CD4 TNF- $\alpha$ & PPD & $0.37(0.1-1.3)$ & $0.57(0-2.1)$ & $\mathbf{0 . 0 3 6}$ \\
& ESAT-6 & $0.39(0.2-2.4)$ & $0.53(0-2.1)$ & 0.651 \\
& CFP-10 & $0.38(0.1-6.7)$ & $0.48(0.1-5.9)$ & 0.826 \\
CD8 TNF- $\alpha$ & PPD & $0.54(0.1-2.0)$ & $0.62(0-4.0)$ & 0.505 \\
& ESAT-6 & $0.47(0.16-3.1)$ & $0.62(0.18-5.1)$ & 0.722 \\
& CFP-10 & $0.47(0-2.8)$ & $0.64(0-3.1)$ & 0.639 \\
& PPD & $0.47(0.0-2.1)$ & $0.58(0-5.9)$ & 0.181 \\
CD4 IL-2 & ESAT-6 & $0.32(0-4.1)$ & $0.53(0.1-1.9)$ & 0.798 \\
& CFP-10 & $0.22(0-4.6)$ & $0.74(0-2.3)$ & 0.639 \\
& PPD & $0.55(0.1-2.3)$ & $0.38(0-4.0)$ & 0.730 \\
CD8 IL-2 & ESAT-6 & $0.42(0.1-2.7)$ & $0.49(0-4.9)$ & 0.791 \\
& CFP-10 & $0.44(0-2.2)$ & $0.24(0-3.2)$ & 0.836 \\
\hline
\end{tabular}

Alexa Fluor 488, and TNF- $\alpha$ PE. To identify the memory cell subset, the cells were stained with CD4 APC or CD8 APC, CD27 PE, CD45RA PE-Cy5, and IFN- $\gamma$ Alexa Fluor 488 (BD Biosciences, San Jose, CA, USA).

2.5. Flow Cytometric Acquisition and Analysis. The sample tubes containing paraformaldehyde-fixed cells were acquired using a FACSCalibur Flow cytometer buffer (BD Biosciences, San Jose, CA, USA). The acquired flow cytometric data were analyzed using FlowJo software (Tree Star Inc., San Carlos, CA, USA) version 7.1.1.

2.6. Statistical Analysis. Statistical analysis was performed using GraphPad Prism version 5.00 for Windows (GraphPad Software, San Diego, CA, USA). Mann-Whitney " $U$ ” test was carried out to calculate the differences between the groups. Receiver operator curve (ROC) analysis was performed to derive the cut-off points.

\section{Results}

3.1. Frequency of Single Cytokine-Secreting T Cells. Table 1 shows the number of PPD-, ESAT-6-, and CFP-10 specific $\mathrm{CD} 4^{+} \mathrm{IFN}-\gamma^{+}$and $\mathrm{CD} 8^{+}$IFN- $\gamma^{+}$T cells upon overnight stimulation of PBMC from $\mathrm{HHC}$ and the TB patients. Although, antigen-specific $\mathrm{CD} 4^{+} \mathrm{IFN}-\gamma^{+} \mathrm{T}$ cells were slightly higher in $\mathrm{TB}$ patients than $\mathrm{HHC}$, the difference did not reach statistical significance. Similarly, the frequency of antigenspecific $\mathrm{CD}^{+}{ }^{+} \mathrm{IFN}-\gamma^{+} \mathrm{T}$ cells also did not differ significantly between $\mathrm{HHC}$ and $\mathrm{TB}$. 


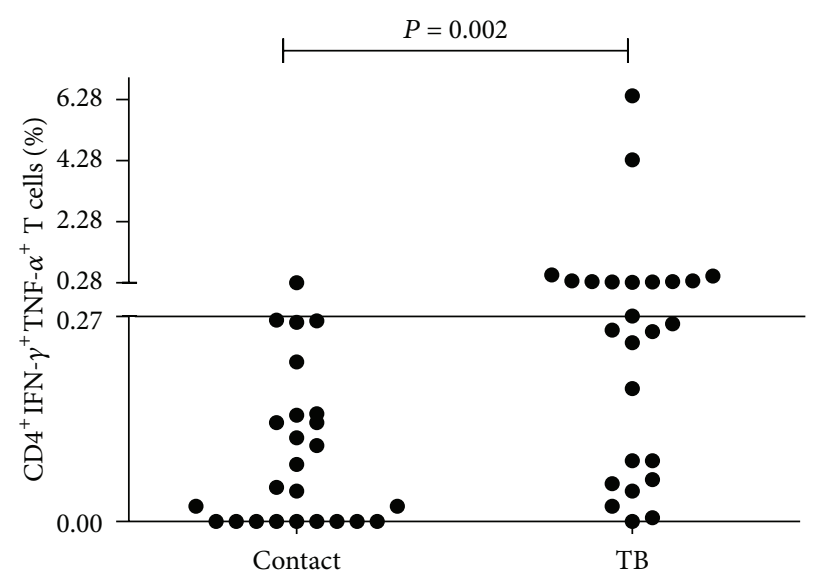

(a)

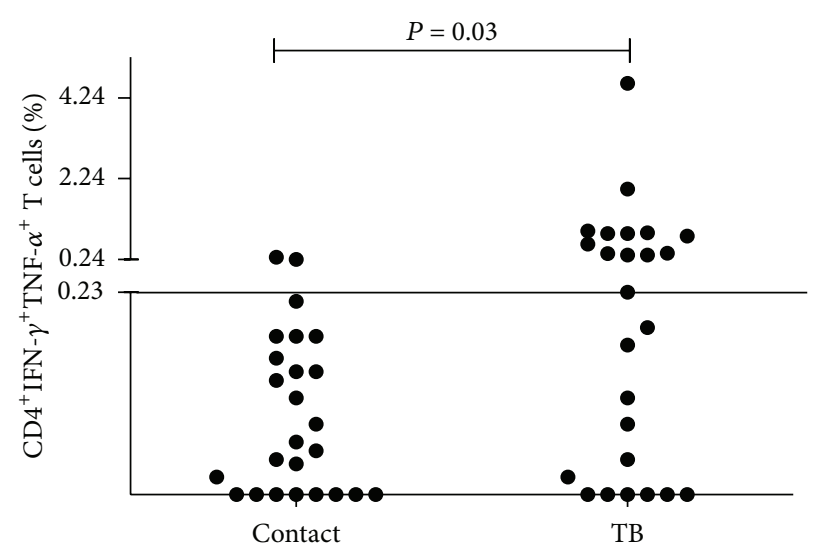

(b)

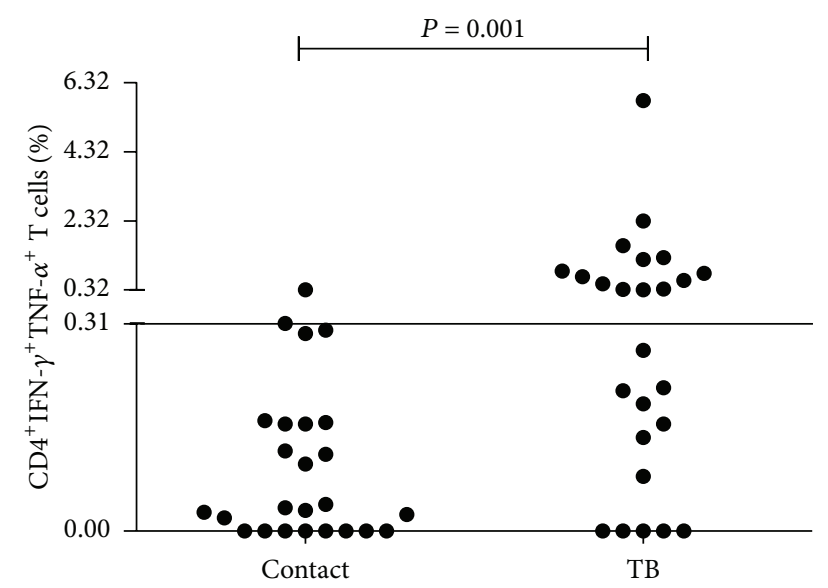

(c)

FIgURE 1: Enumeration of antigen-specific CD4 $4^{+} \mathrm{IFN}-\gamma^{+} \mathrm{TNF}-\alpha^{+} \mathrm{T}$ cells in HHC and TB patients. Scatter plots show antigen-specific $\mathrm{CD} 4^{+}$IFN- $\gamma^{+}$TNF- $\alpha^{+}$T cells in HHC and TB patients. The frequency of antigen-specific ((a) PPD, (b) ESAT-6, and (c) CFP-10) CD4 ${ }^{+}$IFN$\gamma^{+} \mathrm{TNF}-\alpha^{+}$T cells was significantly higher in TB patients compared to HHC for all three antigens. The difference between HHC and TB was calculated by Mann-Whitney $U$ test. TB: tuberculosis patients; HHCs: healthy household contacts.

While the proportion of PPD specific $\mathrm{CD} 4^{+} \mathrm{TNF}-\alpha^{+} \mathrm{T}$ cells was significantly higher in TB patients (median, $0.37 \%$ ) compared to HHC (median, $0.57 \%)(P=0.036)$, ESAT- 6 or CFP-10 specific CD $4^{+}$TNF- $\alpha^{+}$T cells did not differ between those two groups. The proportion of antigen specific $\mathrm{CD} 4^{+} \mathrm{IL}-$ $2^{+}$or $\mathrm{CD}^{+} \mathrm{IL}-2^{+}$cells did not differ between HHC and TB patients (Table 1).

3.2. Frequency of Polyfunctional $T$ Cells. There was an increase in the expression of IFN- $\gamma^{+} \mathrm{IL}_{-} 2^{+}$and IFN- $\gamma^{+}$TNF$\alpha^{+}$(dual cytokine secreting) T cells, when PBMC from HHC and TB patients were stimulated with antigens for overnight. Interestingly, significantly higher frequency of $\mathrm{CD}^{+}{ }^{+} \mathrm{IFN}-$ $\gamma^{+}$TNF- $\alpha^{+}$T cells and CD8 ${ }^{+}$IFN- $\gamma^{+}$TNF- $\alpha^{+}$T cells was observed in TB patients compared to HHC for all the three antigens (PPD, ESAT-6, and CFP-10) used in our study (Figures 1 and 2). Another subset $\mathrm{CD} 4^{+} \mathrm{IFN}-\gamma^{+} \mathrm{IL}-2^{+} \mathrm{T}$ cells or $\mathrm{CD} 8^{+}$IFN- $\gamma^{+}$IL-2 $2^{+}$T cells did not differ between HHC and TB patients (Figure 3 ).
The quantitative increase of IFN- $\gamma^{+} \mathrm{TNF}-\alpha^{+} \mathrm{T}$ cells in TB patients compared to HHC prompted us to calculate the sensitivity and specificity, when the numbers of IFN- $\gamma^{+}$TNF$\alpha^{+}$T cells were enumerated to differentiate HHC and TB patients. We derived cut-off points for each antigen specific of IFN- $\gamma^{+}$TNF- $\alpha^{+}$T cell subset using HHC as controls and $\mathrm{TB}$ patients as diseased.

With a cut-off value 0.255 (AUC, $0.672: 95 \%$ confidence interval (CI), 0.521-0.832) for PPD-specific $\mathrm{CD}^{+}$IFN$\gamma^{+}$TNF- $\alpha^{+}$T cells, 12 out of 25 TB patients and 1 out of 25 HHCs were found to be positive. This yielded a sensitivity of $48 \%$ (95\% CI, $27.8 \%-68.7 \%)$ with a specificity of $96 \%(95 \%$ CI, 74.7\%-99.9\%) (Table 2). The cut-off values 0.225 (AUC, 0.626 : $95 \%$ CI, $0.456-0.795$ ) and 0.310 (AUC, 0.743 : 95\% CI, $0.582-0.905)$ were derived for ESAT-6 and CFP-10 specific of $\mathrm{CD} 4^{+}$IFN $-\gamma^{+} \mathrm{TNF}-\alpha^{+} \mathrm{T}$ cells, respectively. ESAT-6- and CFP-10-specific CD $4^{+}$IFN- $\gamma^{+}$TNF- $\alpha^{+}$T cells showed sensitivities of $48 \%(95 \% \mathrm{CI}, 27.8 \%-68.7 \%)$ and $52 \%$ (95\% CI, $31.3 \%-72.2 \%$ ) with specificities of $100 \%$ and $96 \%$ (95\% CI, 


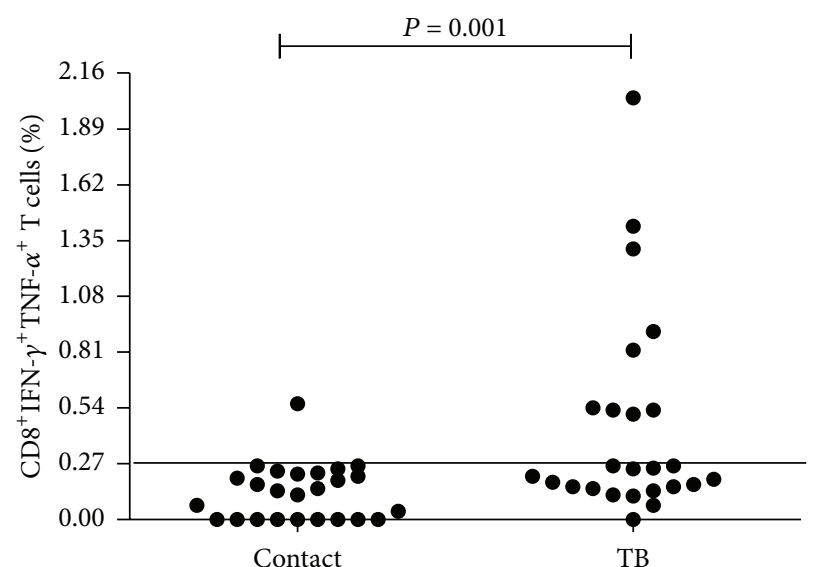

(a)

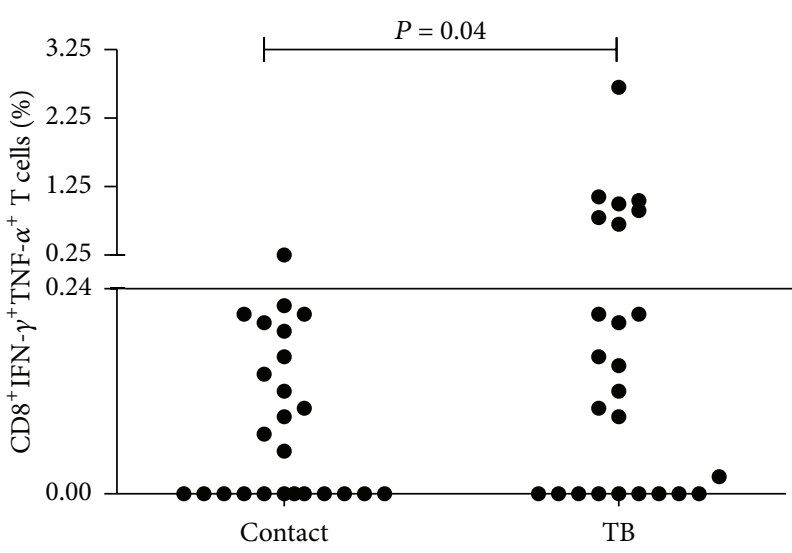

(b)

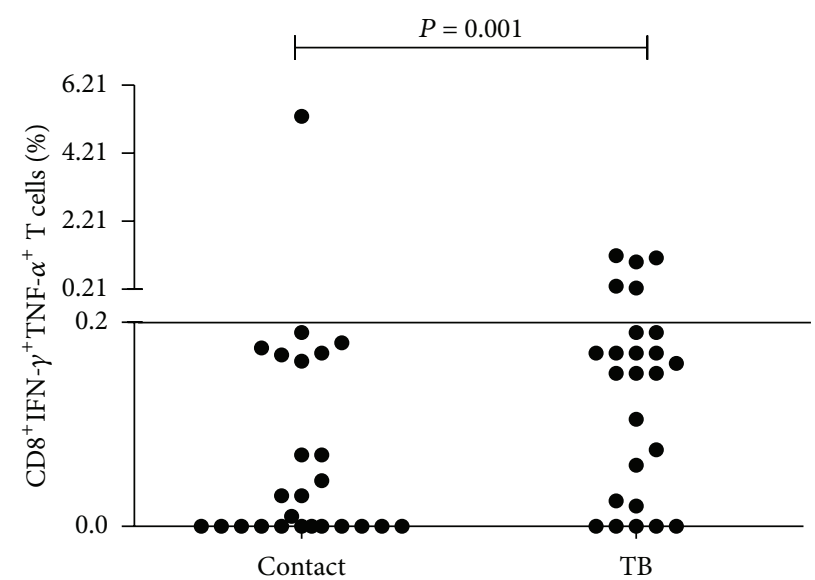

(c)

FIgURE 2: Enumeration of antigen-specific $\mathrm{CD}^{+}$IFN- $\gamma^{+} \mathrm{TNF}-\alpha^{+} \mathrm{T}$ cells in HHC and TB patients. Scatter plots show antigen-specific CD $8^{+}$IFN $-\gamma^{+}$TNF- $\alpha^{+}$T cells in HHC and TB patients. The frequency of antigen ((a) PPD, (b) ESAT-6, and (c) CFP-10) CD8 $8^{+}$IFN- $\gamma^{+}$TNF- $\alpha^{+}$ $\mathrm{T}$ cells was significantly higher in TB patients compared to HHC for all three antigens. The difference between HHC and TB was calculated by Mann-Whitney $U$ test. T: tuberculosis patients; HHCs: healthy household contacts.

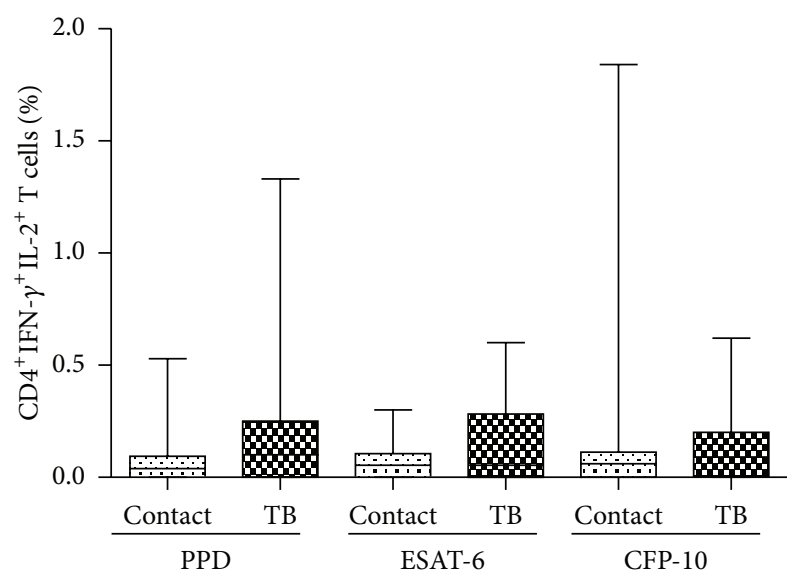

(a)

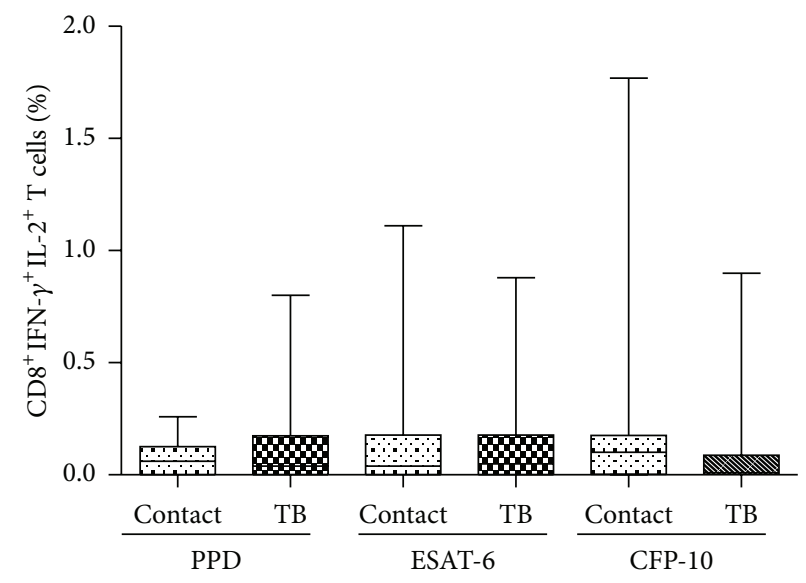

(b)

FIGURE 3: Enumeration of antigen-specific dual cytokine-secreting T cells in HHC and TB patients. Box and Whisker plots show range, interquartile range, and median of antigen-specific CD $4^{+} \mathrm{IFN}-\gamma^{+} \mathrm{IL}-2^{+} \mathrm{T}$ cell (a) and CD8 ${ }^{+} \mathrm{IFN}-\gamma^{+} \mathrm{IL}-2^{+} \mathrm{T}$ cell (b) in $\mathrm{HHC}$ and TB patients. The frequency of IFN- $\gamma^{+} \mathrm{IL}-2^{+} \mathrm{T}$ cell subset did not differ between $\mathrm{HHC}$ and TB patients. The difference between HHC and TB was calculated by Mann-Whitney $U$ test. TB: tuberculosis patients; HHCs: healthy household contacts. 


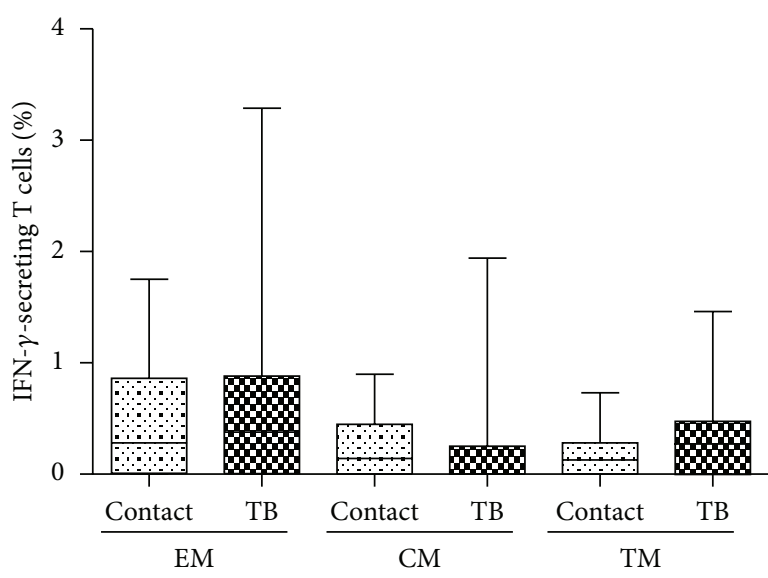

(a)

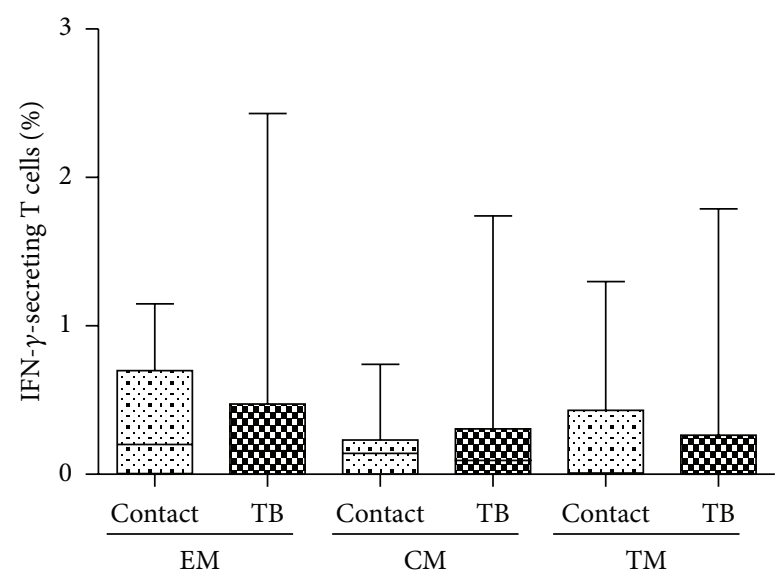

(b)

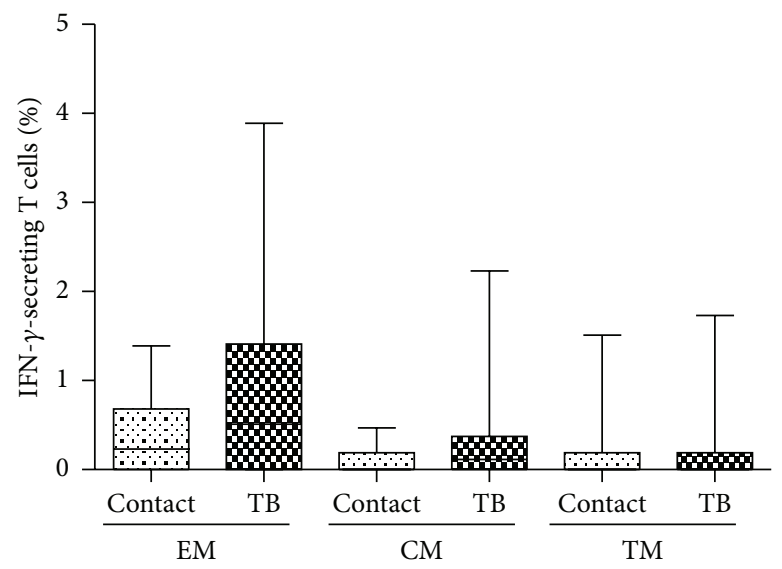

(c)

FIgURE 4: Memory phenotype of antigen-specific CD $4^{+} \mathrm{IFN}-\gamma^{+} \mathrm{T}$ cells in HHC and TB patients. Box and Whisker plots show range, interquartile range, and median of antigen-specific IFN- $\gamma$-secreting memory T cell subsets in HHC and TB patients. Effector memory subset secretes more IFN- $\gamma$ than other memory subsets in HHC and TB patients. The difference between HHC and TB was calculated by MannWhitney test. EM-Effector memory T cell; CM: Central Memory T cell; TM: terminally differentiated memory T cell; TB: tuberculosis patients; HHCs: healthy household contacts.

74.7\%-99.9\%), respectively, for differentiating TB patients and HHC. When the results of ESAT- 6 and CFP-10 were combined, it showed a sensitivity of $68 \%$ with a specificity of $96 \%$.

Similarly, PPD-, ESAT-6-, and CFP-10-specific CD8 ${ }^{+}$IFN$\gamma^{+}$TNF- $\alpha^{+}$T cells showed sensitivities of $36 \%, 20 \%$, and $32 \%$ and specificities of $96 \%$ for diagnosing TB patients. The combination of ESAT- 6 and CFP-10 results did not improve the sensitivity (Table 2).

3.3. Memory T Cell Subtypes. Based on the expression of CD27 and CD45RA, memory subsets can be classified as central memory $\left(\mathrm{CD} 27^{+} \mathrm{CD} 45 \mathrm{RA}^{-}\right)$, effector memory $\left(\mathrm{CD} 27^{-} \mathrm{CD}^{2} \mathrm{RA}^{-}\right)$, and terminally differentiated memory $\left(\mathrm{CD} 27^{-} \mathrm{CD}^{2} 5 \mathrm{RA}^{+}\right)$subsets (49). Frequency of IFN- $\gamma^{+} \mathrm{T}$ cells in all the CD4 and CD8 memory subsets were enumerated (Figures 4 and 5).

Upon overnight stimulation with antigens (PPD, ESAT6, and CFP-10), effector memory subset expressed a significantly higher level of IFN- $\gamma$, compared to terminally differentiated memory and central memory subset. However, the frequency of the IFN- $\gamma$-secreting T cells from any of these $\mathrm{T}$ cell subsets did not differ significantly between $\mathrm{HHC}$ and TB patients.

\section{Discussion}

This study enumerated the number of polyfunctional $\mathrm{T}$ cells in QFT-IT positive HHC and TB patients. In addition, this study also assessed the memory subsets, which were responsible for the secretion of IFN- $\gamma$ in QFT-IT positive $\mathrm{HHC}$ and TB patients during the short-term culture with M. tuberculosis antigens. We used ESAT-6 and CFP-10 antigens to identify $M$. tuberculosis-specific T cells, since these antigens are used in commercial QFT-IT assays. In addition, we also used PPD as it is suggested that it induces IFN- $\gamma$ secretion in $\mathrm{HHC}$, as well as in TB patients.

We found that the numbers of IFN- $\gamma^{+}$TNF- $\alpha^{+}$T cells were significantly higher in TB patients compared to HHC. This is the first study which compared the IFN- $\gamma^{+}$TNF- $\alpha^{+}$ 


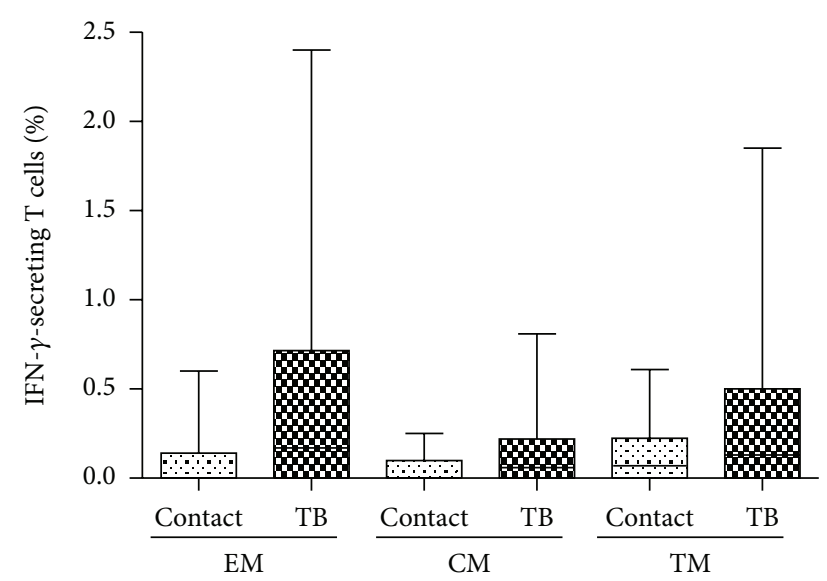

(a)

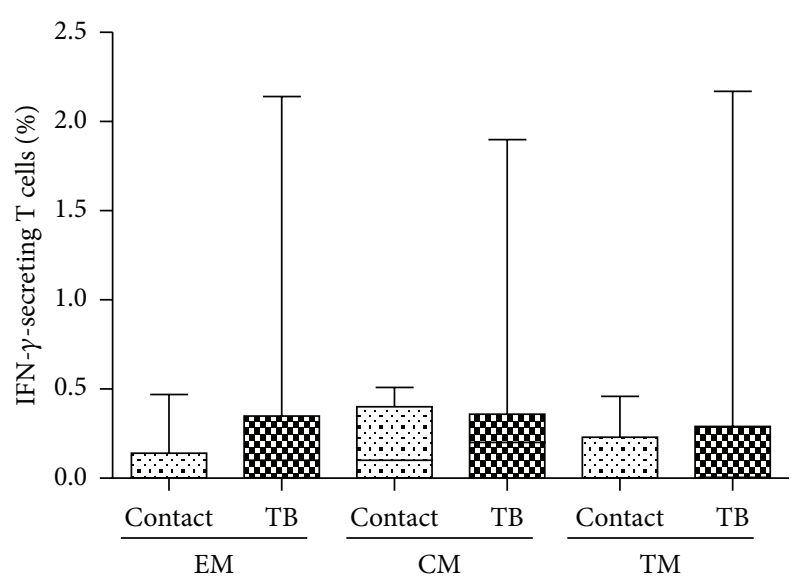

(b)

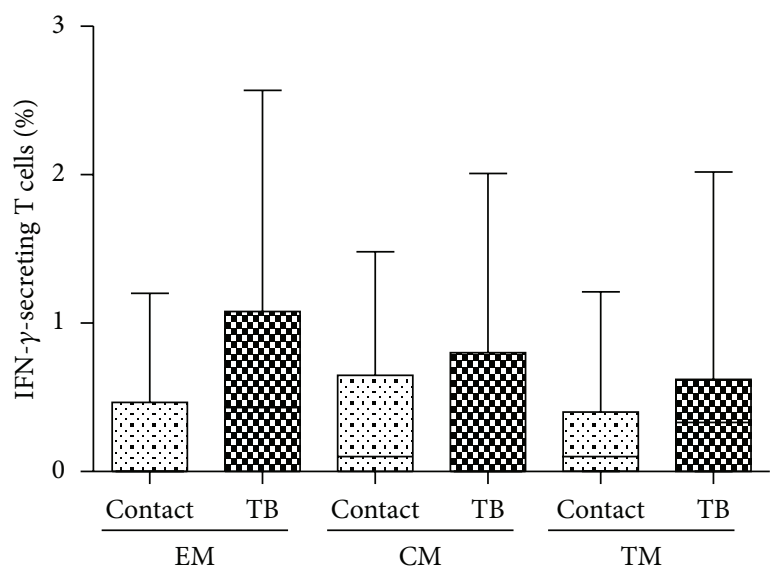

(c)

FIgURE 5: Memory phenotype of antigen-specific $\mathrm{CD} 8^{+} \mathrm{IFN}-\gamma^{+} \mathrm{T}$ cells in $\mathrm{HHC}$ and TB patients. Box and Whisker plots show range, interquartile range, and median of antigen-specific IFN- $\gamma$-secreting memory T cell subsets in HHC and TB patients. Effector memory subset secretes more IFN- $\gamma$ than other memory subsets in HHC and TB patients. The difference between HHC and TB was calculated by MannWhitney test. EM: effector memory T cell; CM: central Memory T cell; TM: terminally differentiated memory T cell; TB: tuberculosis patients; HHCs: healthy household contacts.

TABLE 2: Sensitivity and specificity for CD $4^{+} \mathrm{IFN}-\gamma^{+} \mathrm{TNF}-\alpha^{+}$and $\mathrm{CD} 8^{+} \mathrm{IFN}-\gamma^{+} \mathrm{TNF}-\alpha^{+}$T cells in discriminating HHC and TB patients.

\begin{tabular}{ccccc}
\hline Phenotype & Antigen & Cut-off value & \% Sensitivity (95\% CI) & \% Specificity (95\% CI) \\
\hline \multirow{4}{*}{ CD4 } & PPD & 0.27 & $48(27.8-68.7)$ & $96(79.7-99.9)$ \\
& ESAT-6 & 0.23 & $48(27.8-68.7)$ & 100 \\
CFP-10 & 0.31 & $52(31.3-72.2)$ & $96(74.7-99.9)$ \\
CD8 & ESAT-6 + CFP-10 & & $68(49.7-86.3)$ & $96(79.7-99.9)$ \\
& PPD & 0.27 & $36(18.0-57.5)$ & $96(79.7-99.9)$ \\
& ESAT-6 & 0.24 & $20(6.8-40.7)$ & $96(79.7-99.9)$ \\
& CFP-10 & 0.20 & $32(15-53.5)$ & $96(79.7-99.9)$ \\
\hline
\end{tabular}

T cells between $\mathrm{HHC}$ and TB patients. An earlier study, which was conducted in HIV positive latent TB subjects, also reported higher frequency of IFN- $\gamma^{+}$TNF- $\alpha^{+}$CD 4 cells [20]. However, this study did not compare the number of IFN$\gamma^{+}$TNF- $\alpha^{+}$T cells between latent and active TB patients.

Young et al. also compared the number of single cytokinesecreting $\mathrm{T}$ cells and polyfunctional $\mathrm{T}$ cells in $\mathrm{TB}$ patients before and after chemotherapy and found that the number of polyfunctional $\mathrm{T}$ cells was decreased after successful TB therapy [21]. During the chronic infection with $M$. tuberculosis, the host slowly loses the important characteristics of the immune cells such as cytokine secretion and cytolytic property [22]. We speculate that the exhaustion of T cells in the TB infected individuals endows T cells with polyfunctions 
such as the secretion of more than a single cytokine. This might be the reason for the higher number of IFN- $\gamma^{+}$TNF$\alpha^{+}$polyfunctional T cells in TB patients compared to HHC in our study. Due to the small number of study subjects in each group, we could not find any association between clinical outcome and changes in the number of polyfunctional $\mathrm{T}$ cells. Therefore, further studies are needed to confirm the role of polyfunctional $\mathrm{T}$ cells in protective mechanism against TB.

On the other hand, we found that the number of single (either IFN- $\gamma$ or TNF- $\alpha$ ) cytokine-secreting T cells did not differ between these two groups, except the PPD-specific TNF- $\alpha$. This study results corroborates with our earlier observations $[23,24]$. PPD-specific TNF- $\alpha$ was significantly higher in TB patients compared to HHC. The recent study conducted by Harari et al. also found that TB patients were found to have higher frequency of antigen-pecific TNF$\alpha$ compared to subjects with latent TB [25]. However, the number of ESAT-6- and CFP-10-specific TNF- $\alpha$ did not differ between TB patients and HHC in our study.

When we analyzed the sensitivity and specificity of antigen-specific $\mathrm{CD} 4^{+} \mathrm{IFN}-\gamma^{+} \mathrm{TNF}-\alpha^{+}$, in differentiating HHC and TB patients, the combination of ESAT- 6 and CFP-10 CD $4^{+}$IFN- $\gamma^{+}$TNF- $\alpha^{+}$showed a moderate sensitivity of $68 \%$ with a specificity of $96 \%$. CD $8^{+}$IFN- $\gamma^{+}$TNF- $\alpha^{+}$T cells could produce only $36 \%$ of sensitivity with a specificity of $96 \%$. There was no difference in demographic details or clinical and bacteriological features between the TB patients which were dual cytokine positive and those who were negative. Therefore, further studies with larger number of study subjects are needed to answer why few of the TB patients in this study had low number of IFN- $\gamma^{+}$TNF- $\alpha^{+}$ T cells, similar to HHC. Further studies have to also test the sensitivity of IFN- $\gamma^{+}$TNF- $\alpha^{+}$T cells in smear negative, clinically diagnosed $\mathrm{TB}$ cases, where confirmation of $\mathrm{TB}$ is difficult. Furthermore, the cut-off points calculated in the study for $\mathrm{CD} 4^{+} \mathrm{IFN}-\gamma^{+} \mathrm{TNF}-\alpha^{+} \mathrm{T}$ cells also have to be reconfirmed with large number of study subjects.

The profile of IFN $-\gamma^{+} \mathrm{IL}-2^{+} \mathrm{T}$ cells was studied in various viral infections and TB patients [26-31]. In many of the earlier studies, IFN- $\gamma^{+} \mathrm{IL}-2^{+}$T cells were suggested as positive correlates to the protection. Antigen clearance of past influenza infection was correlated with CD4 T cells secreting IFN$\gamma^{+} \mathrm{IL}^{+} 2^{+}$[27]. While high viral load in cytomegalovirus was associated with high number of IFN- $\gamma$ alone positive T cells, the subjects with low viral load had high number of IFN$\gamma^{+} \mathrm{IL}^{+} \mathrm{2}^{+}$dual cytokine-secreting T cells [28]. Similar trend was observed for other viral infections such as hepatitis $\mathrm{C}$ virus, HSV, Epstein-Barr Virus, and HIV [29-31]. The TB patients, who have completed successful anti TB treatment, were found to have higher frequency of IFN $-\gamma^{+} \mathrm{IL}-2^{+}$or IFN$\gamma^{+}$IL-2 $2^{+}$TNF- $\alpha^{+}$T cells $[32,33]$.

Based on the above observations, we expected that number of IFN- $\gamma^{+} \mathrm{IL}-2^{+} \mathrm{T}$ cells would be higher in HHC compared to TB patients. However, this trend was not found in our study. There was less number of IFN- $\gamma^{+} \mathrm{IL}_{-} 2^{+} \mathrm{T}$ cells, similar to TB, in HHC. An earlier study conducted in subjects with latent TB and HIV-1 infection also reported a fewer number of IFN- $\gamma^{+}$IL-2 ${ }^{+}$T cells [20].
Based on the expression of phenotypic markers CD45RA and $\mathrm{CD} 27$, the antigenic memory cells are classified as effector memory $\mathrm{T}$ cells, central memory $\mathrm{T}$ cells, terminally differentiated $\mathrm{T}$ memory cells, and naïve cells. The present study results indicate that the effector memory $\mathrm{T}$ cells secrete IFN- $\gamma$ in response to $M$. tuberculosis-specific antigens during the short-term incubation. This study results corroborate with the earlier study results conducted by Goletti et al. [34]. But some of the antigen specific cells were having CD45RA ${ }^{+}$ and $\mathrm{CD} 27^{-}$phenotype. This indicates that the terminally differentiated effector T cells also secrete IFN- $\gamma$, to some extent, in response to $M$. tuberculosis antigens during the short-term incubation. However, number and phenotype of IFN- $\gamma$-secreting T cell were similar in HHC and TB patients.

Altogether, this study concludes that TB patients were found to have higher number of IFN- $\gamma^{+} \mathrm{TNF}-\alpha^{+} \mathrm{T}$ cells, compared to HHC. The effector memory subset, with a phenotype of CD45RA-CD27-T cells, plays an important role in the secretion of IFN- $\gamma$ compared to other subsets during short term incubation with TB antigens.

\section{Conflict of Interests}

The authors declare that they have no conflict of interests, including specific financial interests or relationships or affiliations to the subject matter or materials discussed in the paper.

\section{Acknowledgments}

The authors wish to thank all the study subjects, who participated in this study. The technical help contributed by Mr. Murugesan in flow cytometry experiments is highly acknowledged. Basirudeen Syed Ahamed Kabeer is the recipient of Senior Research Fellowship from the Indian Council of Medical Research (ICMR), New Delhi, India.

\section{References}

[1] WHO, 2008, Tuberculosis Facts. Stop TB partnership, pp 1-2, http://www.who.int/tb/publications/2008/factsheet_april08 .pdf.

[2] L. Goldsack and J. R. Kirman, "Half-truths and selective memory: interferon gamma, $\mathrm{CD} 4^{+} \mathrm{T}$ cells and protective memory against tuberculosis," Tuberculosis, vol. 87, no. 6, pp. 465-473, 2007.

[3] J. L. Flynn, "Immunology of tuberculosis and implications in vaccine development," Tuberculosis, vol. 84, no. 1-2, pp. 93-101, 2004.

[4] E. van de Vosse, M. A. Hoeve, and T. H. M. Ottenhoff, "Human genetics of intracellular infectious diseases: molecular and cellular immunity against mycobacteria and salmonellae," The Lancet Infectious Diseases, vol. 4, no. 12, pp. 739-749, 2004.

[5] O. Filipe-Santos, J. Bustamante, A. Chapgier et al., "Inborn errors of IL-12/23- and IFN-gamma-mediated immunity: molecular, cellular, and clinical features," Seminars in Immunology, vol. 18, pp. 347-361, 2006.

[6] D. L. Barber, E. J. Wherry, D. Masopust et al., "Restoring function in exhausted CD8 T cells during chronic viral infection," Nature, vol. 439, no. 7077, pp. 682-687, 2006. 
[7] S. D. Blackburn, H. Shin, W. N. Haining et al., "Coregulation of $\mathrm{CD}^{+} \mathrm{T}$ cell exhaustion by multiple inhibitory receptors during chronic viral infection," Nature Immunology, vol. 10, no. 1, pp. 29-37, 2009.

[8] C. L. Day, D. E. Kaufmann, P. Kiepiela et al., "PD-1 expression on HIV-specific T cells is associated with T-cell exhaustion and disease progression," Nature, vol. 443, no. 7109, pp. 350-354, 2006.

[9] R. B. Jones, L. C. Ndhlovu, J. D. Barbour et al., "Tim-3 expression defines a novel population of dysfunctional $\mathrm{T}$ cells with highly elevated frequencies in progressive HIV-1 infection," Journal of Experimental Medicine, vol. 205, no. 12, pp. 27632779, 2008 .

[10] D. E. Kaufmann, D. G. Kavanagh, F. Pereyra et al., "Upregulation of CTLA- 4 by HIV-specific $\mathrm{CD}^{+}{ }^{+} \mathrm{T}$ cells correlates with disease progression and defines a reversible immune dysfunction," Nature Immunology, vol. 8, no. 11, pp. 1246-1254, 2007.

[11] S. Urbani, B. Amadei, D. Tola et al., "PD-1 expression in acute hepatitis $\mathrm{C}$ virus (HCV) infection is associated with $\mathrm{HCV}$ specific CD8 exhaustion," Journal of Virology, vol. 80, no. 22, pp. 11398-11403, 2006.

[12] S. Kannanganat, C. Ibegbu, L. Chennareddi, H. L. Robinson, and R. R. Amara, "Multiple-cytokine-producing antiviral CD4 $\mathrm{T}$ cells are functionally superior to single-cytokine-producing cells," Journal of Virology, vol. 81, no. 16, pp. 8468-8476, 2007.

[13] G. Makedonas and M. R. Betts, "Living in a house of cards: Re-evaluating $\mathrm{CD}^{+}$T-cell immune correlates against HIV," Immunological Reviews, vol. 239, no. 1, pp. 109-124, 2011.

[14] S. Kannanganat, B. G. Kapogiannis, C. Ibegbu et al., "Human immunodeficiency virus type 1 controllers but not noncontrollers maintain CD4 T cells coexpressing three cytokines," Journal of Virology, vol. 81, no. 21, pp. 12071-12076, 2007.

[15] M. R. Betts, M. C. Nason, S. M. West et al., "HIV nonprogressors preferentially maintain highly functional $\mathrm{HIV}$-specific $\mathrm{CD} 8^{+} \mathrm{T}$ cells," Blood, vol. 107, no. 12, pp. 4781-4789, 2006.

[16] D. Ciuffreda, D. Comte, M. Cavassini et al., "Polyfunctional HCV-specific T-cell responses are associated with effective control of HCV replication," European Journal of Immunology, vol. 38, no. 10, pp. 2665-2677, 2008.

[17] P. A. Darrah, D. T. Patel, P. M. De Luca et al., "Multifunctional TH1 cells define a correlate of vaccine-mediated protection against Leishmania major," Nature Medicine, vol. 13, no. 7, pp. 843-850, 2007.

[18] E. K. Forbes, C. Sander, E. O. Ronan et al., "Multifunctional, high-level cytokine-producing Th1 cells in the lung, but not spleen, correlate with protection against Mycobacterium tuberculosis aerosol challenge in mice," Journal of Immunology, vol. 181, no. 7, pp. 4955-4964, 2008.

[19] N. Caccamo, G. Guggino, S. A. Joosten et al., "Multifunctional $\mathrm{CD}^{+}{ }^{+} \mathrm{T}$ cells correlate with active Mycobacterium tuberculosis infection," European Journal of Immunology, vol. 40, no. 8, pp. 2211-2220, 2010.

[20] C. L. Day, N. Mkhwanazi, S. Reddy et al., "Detection of polyfunctional Mycobacterium tuberculosis-specific T cells and association with viral load in HIV-1-infected persons," Journal of Infectious Diseases, vol. 197, no. 7, pp. 990-999, 2008.

[21] J. M. Young, I. M. O. Adetifa, M. O. C. Ota, and J. S. Sutherland, "Expanded polyfunctional $\mathrm{T}$ cell response to mycobacterial antigens in TB disease and contraction post-treatment," PLoS ONE, vol. 5, no. 6, Article ID el1237, 2010.
[22] K. A. Millington, J. A. Innes, S. Hackforth et al., "Dynamic relationship between IFN- $\gamma$ and IL-2 profile of Mycobacterium tuberculosis-specific T cells and antigen load," Journal of Immunology, vol. 178, no. 8, pp. 5217-5226, 2007.

[23] M. Kumar, N. Meenakshi, J. C. Sundaramurthi, G. Kaur, N. K. Mehra, and A. Raja, "Immune response to Mycobacterium tuberculosis specific antigen ESAT-6 among south Indians," Tuberculosis, vol. 90, no. 1, pp. 60-69, 2010.

[24] M. Kumar, J. C. Sundaramurthi, N. K. Mehra, G. Kaur, and A. Raja, "Cellular immune response to Mycobacterium tuberculosis-specific antigen culture filtrate protein-10 in South India," Medical Microbiology and Immunology, vol. 199, no. 1, pp. 11-25, 2010.

[25] A. Harari, V. Rozot, F. B. Enders et al., "Dominant TNF- $\alpha^{+}$ Mycobacterium tuberculosis-specific $\mathrm{CD}^{+}{ }^{+} \mathrm{T}$ cell responses discriminate between latent infection and active disease," Nature Medicine, vol. 17, no. 3, pp. 372-376, 2011.

[26] A. J. Zajac, J. N. Blattman, K. Murali-Krishna et al., "Viral immune evasion due to persistence of activated T cells without effector function," Journal of Experimental Medicine, vol. 188, no. 12, pp. 2205-2213, 1998.

[27] M. Lucas, C. L. Day, J. R. Wyer et al., "Ex vivo phenotype and frequency of influenza virus-specific CD4 memory T cells," Journal of Virology, vol. 78, no. 13, pp. 7284-7287, 2004.

[28] J. P. Casazza, M. R. Betts, D. A. Price et al., "Acquisition of direct antiviral effector functions by CMV-specific $\mathrm{CD} 4^{+} \mathrm{T}$ lymphocytes with cellular maturation," Journal of Experimental Medicine, vol. 203, no. 13, pp. 2865-2877, 2006.

[29] S. C. Derrick, I. M. Yabe, A. Yang, and S. L. Morris, "Vaccineinduced anti-tuberculosis protective immunity in mice correlates with the magnitude and quality of multifunctional CD4 T cells," Vaccine, vol. 29, no. 16, pp. 2902-2909, 2011.

[30] P. Klenerman and A. Hill, "T cells and viral persistence: lessons from diverse infections," Nature Immunology, vol. 6, no. 9, pp. 873-879, 2005.

[31] A. Harari, S. Petitpierre, F. Vallelian, and G. Pantaleo, "Skewed representation of functionally distinct populations of virusspecific CD4 T cells in HIV-1-infected subjects with progressive disease: changes after antiretroviral therapy," Blood, vol. 103, no. 3, pp. 966-972, 2004.

[32] C. L. Day, D. A. Abrahams, L. Lerumo et al., "Functional capacity of Mycobacterium tuberculosis-specific T cell responses in humans is associated with mycobacterial load," Journal of Immunology, vol. 187, no. 5, pp. 2222-2232, 2011.

[33] U. Sester, M. Fousse, J. Dirks et al., "Whole-blood flowcytometric analysis of antigen-specific CD4 T-cell cytokine profiles distinguishes active tuberculosis from non-active states," PLoS ONE, vol. 6, no. 3, Article ID e17813, 2011.

[34] D. Goletti, O. Butera, F. Bizzoni, R. Casetti, E. Giradi, and F. Poccia, "Region of difference 1 antigen-specific $\mathrm{CD} 4^{+}$memory T cells correlate with a favorable outcome of tuberculosis," Journal of Infectious Diseases, vol. 194, no. 7, pp. 984-992, 2006. 


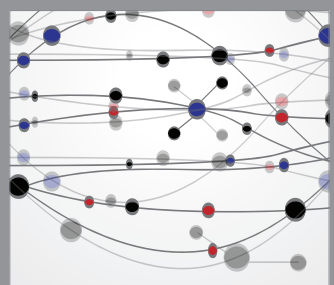

The Scientific World Journal
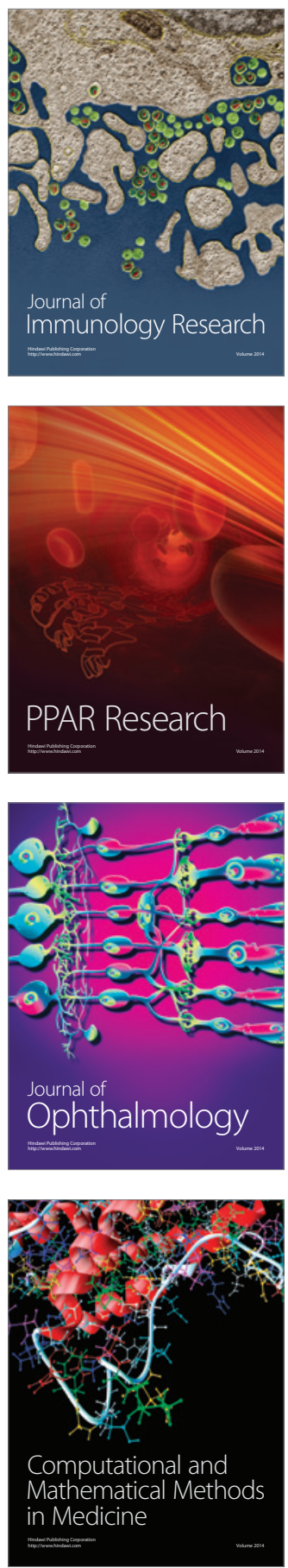

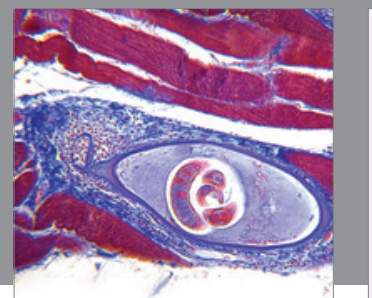

Gastroenterology

Research and Practice
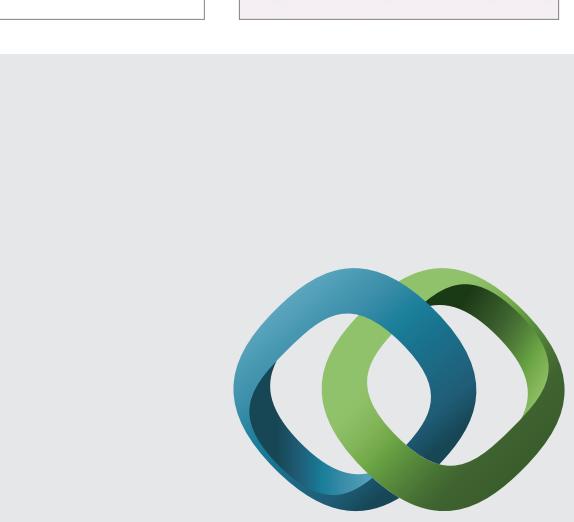

\section{Hindawi}

Submit your manuscripts at

http://www.hindawi.com
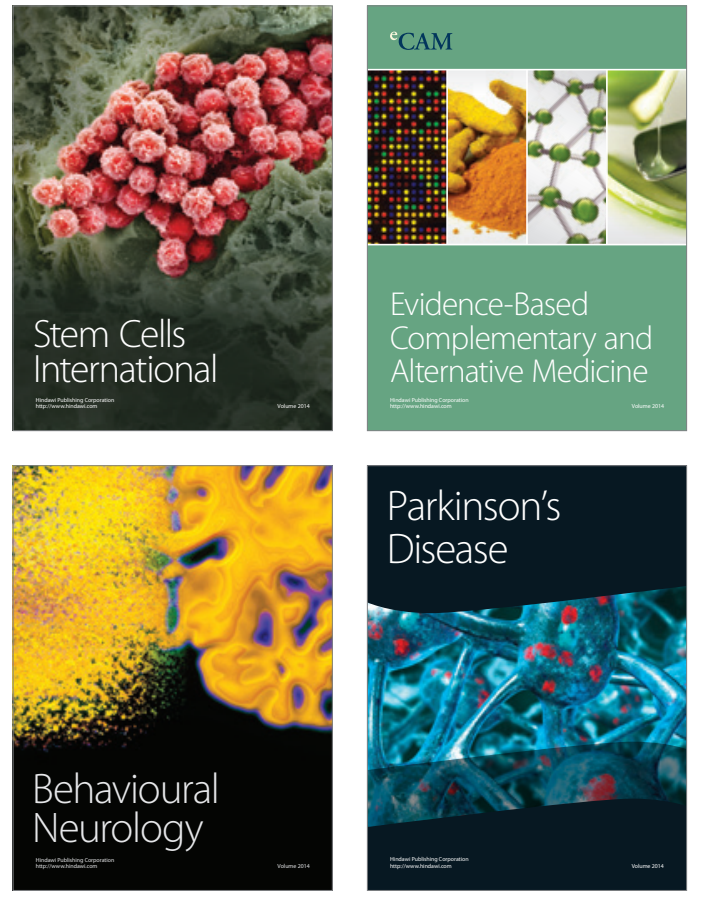
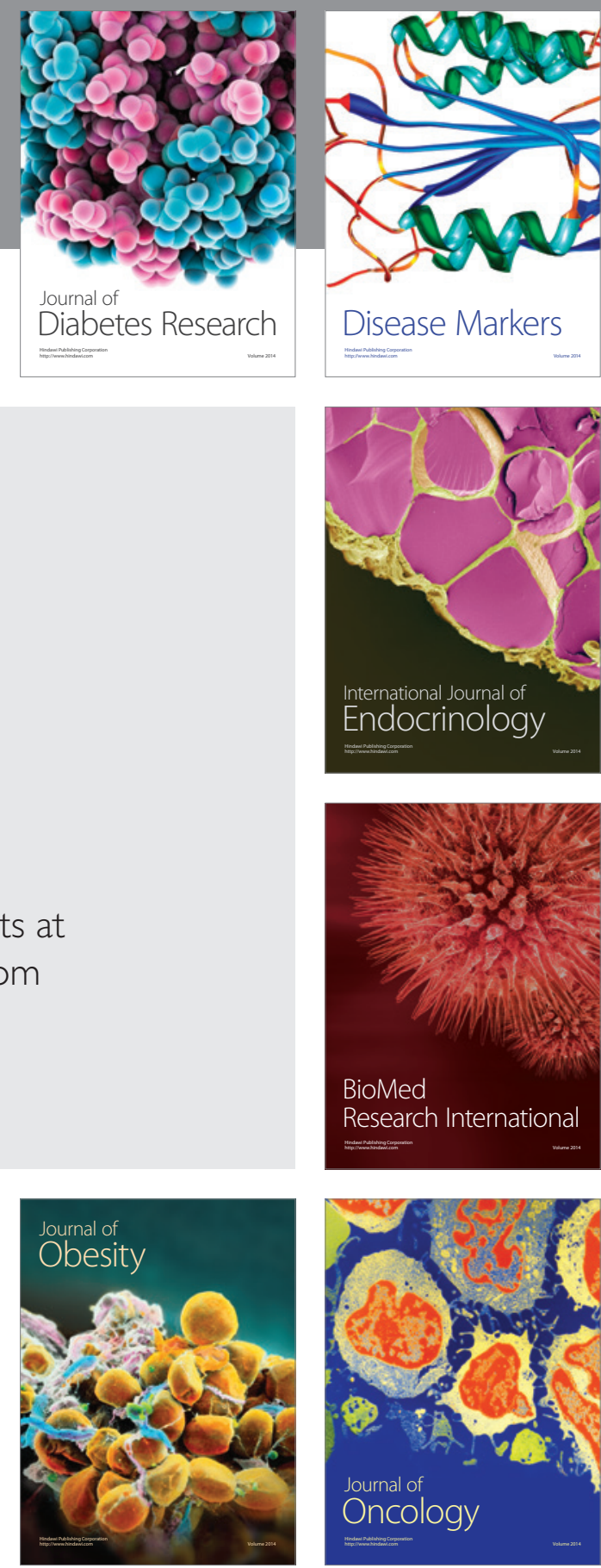

Disease Markers
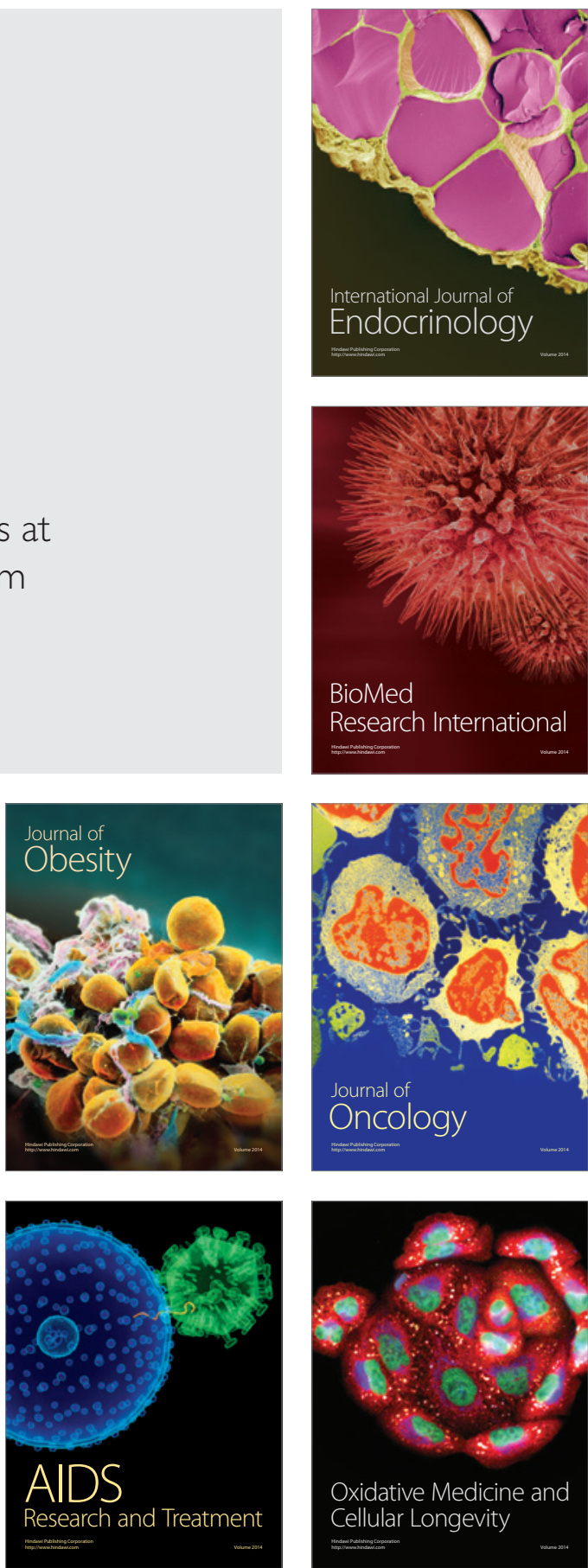